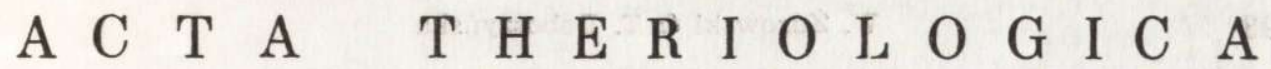

VOL. $20,7: 97-104$.

April, 1975

\author{
Wirgiliusz ŻUROWSKI \& Teresa DOBOSZYŃSKA
}

\section{Superfoetation in European Beaver}

\author{
[With 1 Table \& Plates $\mathrm{I}-\mathrm{II}]$
}

\begin{abstract}
Six cases of oestrus in European beaver (Castor fiber L in na e us, 1785) females occuring during pregnancy are described. Histological analyses of ovaries and of the reproductive tract of the dead females, as well as vaginal smears, have revealed a high activity of ovaries during pregnancy. Kits differing in size and the degree of hairiness has been observed in two obnormal litters of two females. The ovaries of one of these females which died at parturition, contained corpora lutea at different stages of development. These facts indicates the possibility of superfoetation in beaver.
\end{abstract}

\section{INTRODUCTION}

Beavers belong to polyestrous animals with a well-defined breeding season. Within a typical mating season which lasts from the end of December until the beginning of March there take place a few oestrous cycles, usually occurring at irregular time intervals governed by climatic conditions. The normal reproductive rhythm runs, therefore, as follows: oestrous, successful covering, gestation lasting of the average 107 days, parturition, period of lactation extending under farm conditions nearly three months ( $\dot{Z}$ u rowski et al., 1974). Afterwards ensues a period of sexual inactivity lasting about 165 days. Under farm breeding of beavers, though, certain anomalies have been observed in the process of reproduction. It may be interesting to report these anomalies as a contribution to the knowledge of the reproduction of the European beaver, and important for breeding practice.

\section{MATERIAL AND METHODS}

Observations of the symptoms of the mating season and the recurrence of heat were carried out at the Experimental Farm Popielno in 1971-1973. During the 
period of heat there take place discharges from the reproductive tracts of females, also a perceivable excitement of the animals. Records have been taken of the dates of occurrence of these symptoms, as well as of cases of noticed coverings. Furthermore, from the reproductive organs of three females (nos. 24, 36 and 49) which had died at the farms of Popielno and Wiartel material was taken for histological investigations. The ovaries were fixed in $A F A$ fluid, dehydrated in alcohol and xylene, then embedded in paraffin. Transverse microscopic sections were stained by Mallory's method (B a giński, 1969). Sections from oviducts, the uterus and vagina were fixed in Bouin's fluid and stained in haemotoxylineosin. Vaginal smears of female no. 35 were taken by original method, involving the use of a special glass spoon protected with a glass tube $6 \mathrm{~mm}$ in diameter. The smears were then fixed and stained by Krupiński's method modified by Doboszyńska (Krupiński, 1955).

\section{RESULTS}

In the breeding season of $1971-1973$, there were noticed symptoms of heat and eaven copulations among pregnant females (Table 1). These observations suggest persistence of a high activity of ovaries during the mating season, despite the onset of pregnancy. These assumptions have been confirmed by morpho-histological analyses carried out on organs of dead females. The females no. 36 and 49 were bitten to death on Feb. 24 and March 3, 1970, hence towards the closing of the regular breeding season. The uterus of female no. 36 was found to contain two resorbed embryos, $2 \times 3 \mathrm{~cm}$ in dimensions; whereas in female no. 49 there were three embryos undergoing the process of resorbtion, the largest of them $3 \times 4 \mathrm{~cm}$ in size (Fig. 1). Ovaries of these females displayed a similar histological picture indicating recent ovulations. The left ovary of female no. 36 contained seven disrupted Graafian follicles of which corpora lutea became formed. Three of the latter were in the stage of corpus hemorrhagicum with blood clot, while the remaining ones owed their origin to somewhat earlier ovulations, with blood clots beguning to undergone organization (Fig. 2). The right ovary held nine disrupted Graafian follicles, two of which occurred in the form of corpus hemorrhagicum. In the left ovary of female no. 49, there were six ruptured Graafian follicles, one of which was in the corpus hemorrhagicum stage, while the remaining ones in the corpus luteum organizing stage. On the other hand, in the right ovary were five corpora lutea and a single corpus hemorrhagicum. In both females, the ovaries contained corpora lutea of pregnancy as well as Graafian follicles approaching maturation.

Oviducts of female beavers are made up of the following layers: mucous membrane protected with a unistratal, cylindrical epithelium; circular and longitudinal muscular coat; a serous membrane coat (D o boszynska, 1970). They respond to the activity of the ovary by 
changes in thickness of the different layers. Ovulation in females no. 36 ard 49 caused a softening of the mucous layer of the oviducts, the appearance of numerous folds and formation of high, ciliated cells of the epithelium. In both females the caves of the uteri were closed, the micous membrane being very thick, softened and congested. The epithelium were characteristic for the secretory phase of the uterus (Fig. 3).

Table 1

Symptoms of heat observed in females of European beaver.

\begin{tabular}{|c|c|c|c|c|}
\hline $\begin{array}{l}\text { No of } \\
\text { fenale }\end{array}$ & $\begin{array}{l}\text { Date of success- } \\
\text { ful covering }\end{array}$ & $\begin{array}{c}\text { Dates of observed } \\
\text { symptoms of } \\
\text { heat }^{-1}\end{array}$ & $\begin{array}{c}\text { Dates of } \\
\text { copulations }\end{array}$ & $\begin{array}{c}\text { Dates of } \\
\text { parturitions }\end{array}$ \\
\hline $7 t$ & Jan. 18, 1971 & $\begin{array}{lr}\text { Dec. } & 30,1970 \\
\text { Jan. } & 9,1971 \\
\text { Jan. } & 18,1971 \\
\text { Feb. } & 5,1971 \\
\text { March } & 9,1971\end{array}$ & & May 5,1971 \\
\hline 41 & Jan. 10, 1971 & $\begin{array}{ll}\text { Dec. } & 30,1970 \\
\text { Jan. } & 10,1971 \\
\text { Jan. } & 18,1971\end{array}$ & $\begin{array}{ll}\text { Dec. } & 30,1970 \\
\text { Jan. } & 10,1971\end{array}$ & April 25, 1971 \\
\hline 73 & Jan: 19,1972 & $\begin{array}{lr}\text { Jan. } & 10,1972 \\
\text { Feb. } & 9,1972 \\
\text { Feb. } & 16,1972 \\
\text { March } & 3,1972\end{array}$ & March 3, 1972 & \\
\hline 75 & Jan. 10, 1972 & $\begin{array}{ll}\text { Jan. } & 10,1972 \\
\text { Jan. } & 12,1972 \\
\text { Jan. } & 20,1972 \\
\text { Jan. } & 27,1972\end{array}$ & Feb. $\quad 16,1972$ & $\begin{array}{l}\text { May } 6,1972 \\
\text { April } 26,1972\end{array}$ \\
\hline 73 & Feb. $\quad 9,1973$ & $\begin{array}{lr}\text { Dec. } & 23,1972 \\
\text { Jan. } & 4,1973 \\
\text { Jan. } & 29,1973 \\
\text { March } & 5,1973\end{array}$ & 4,1973 & May 26,1973 \\
\hline 111 & Jan. 30,1973 & $\begin{array}{lr}\text { Jan. } & 5,1973 \\
\text { Jan. } & 12,1973 \\
\text { Jan. } & 30,1973 \\
\text { Feb. } & 14,1973\end{array}$ & & May 18,1973 \\
\hline
\end{tabular}

1 The act of covering can be observed in the farm if it takes place in the open resirvoir; ${ }^{2}$ In a vast majority of cases symptoms of oestrus persist over a period of i few days. Reported are dates of the first day on which symptoms were noticed.

Uterine glands occurred in large numbers and their size increased. In both females the vagina was lined with a very thick layer of proliferated mucous membrane, the multistratified squamous, keratic epitheium had about 12 layers. Desquamation of large groups of enucleate comified cells of the epithelium indicate a phase of heat (Fig. 4).

To find out if there exist high ovarian activity after successful mating vainal smears were collected from female no. 34 on May 23 and 24, duing the first half of the gestation, this female was covered on May 2, 1973. The vaginal smears taken on May 23 indicated of oestrus, further 
smears had not been collected to avoid possible interfering with the pregnancy. The female gave birth on Aug. 16, 1973, a litter of four normally developed kits. The delayed reproduction in this female was connected by other experiments.

The events described above may prove helpful in explaining cases of abnormal parturitions in females no. 24 and 46. At the Popielno farm, female no. 24 gave birth on May 19, 1970, to a single normal young, which died after the delivery. Six days later, on May 25, the same female gave birth to two more young beavers. This time the animals were underdeveloped, scantily covered with hair, dead. Next morning this female gave birth to still another young, dead in spite of its, normal development. Parturition having ceased, but examination through abdominal wall indicated the presence of another foetus, Caesarean section was started. However, the greatly exhausted female died after injection of Combelen. Post-mortem examination revealed in the uterus two more foetuses, one of them hairy and of normal size, the other naked and much smaller.

At the Wiartel farm, on June 11, 1972, female no. 46, multipara, gave birth to five kits, three of which were fully developed and alive, while two were much smaller, bare and dead.

During histological examination of female no. 24, corpora lutea of pregnancy at different stages of development have been found in the ovaries. The left ovary contained two well-developed corpora lutea of pregnancy; whereas in the right ovary there was one fully developed corpus luteum and three corpora lutea in the process of regression (Fig. 5). Fully-developed corpora lutea situated immediately below the tunica albuginea were oval-shaped, surrounded by well vascularized theca folliculi. Luteal and paraluteal cells were arranged radially around the vesicular cavity of the corpus luteum. These corpora lutea were much larger thant the Graafian follicles before maturity. Regression corpora lutea were within the inner part of the cortical partion. They were much smaller than the formed ones and than Graafian follicles (Fig. 5), and displayed a complete atrophy of the follicular cavity and proliferation of connective tissue deep into the parenchyma of the corpus luteum. In structure they were similar to corpora albuginea observed in the other females a few months after gestation. In this female the ovaries contained also maturing Graafian follicles and arthritic follicles (Fig. 5). In the oviduct of female no. 24 the muscular coat was rather thick, while the mucous membrane was thin and with only few folds, covered by a single layered not high, columnal epithelium. The epithelium contained secretory cells. There were very few ciliated cells. Free segments of the uterus were provided with a well-developed muscular coat. The 
mucous membrane of the uterus was comparatively thin, the rather small uterine glands produced no secretion, and the unistratal epithelium was rather low (Fig. 6). Presumably the process of involution of the mucous membrane of the uterus was already under way. The low mucous membrane of the vagina covered with a stratifical squamous epithelium had no inclination to proliferate, there were no keratic cells, nucleated ones on the other hand being present (Fig. 7). The histological picture of the vagina was not yet influenced by the Graafian follicles maturing in the ovaries.

\section{DISCUSSION}

All the above described facts prove that both cases of abnormal parturitions were caused by the phenomenon of superfoetation. Changes found in the reproductive systems of the examined females correspond with the scheme leading to superfoetation in mammals as reported by $\mathrm{N}$ a l b a nd ow (1966). R ol hä u s e r (1949) described superfoetation in mice, ended in two successive and successful parturitions. Cases of superfoetation in small rodents have been reported by B u r r o w s (1941), Slonaker (1934) as well as by Bilewicz \& Minkiewiczowa (1954); whereas in swine and sheep by S mith (1927a and 1927b) Occurrence of superfoetation in hares kept in captivity has been proved in many cases ( $\mathrm{H} \mathrm{e} \mathrm{dig} \mathrm{e} \mathrm{r,} \mathrm{1948;} \mathrm{J} \mathrm{a} \mathrm{c} \mathrm{obs,} \mathrm{1966).} \mathrm{In} \mathrm{hares,} \mathrm{moreover,}$ there has been discovered the possibility for the semen translocation to the opposite oviduct through the pregnant corner of the uterus, at the beginning of gestation (B loch et al., 1967). Occurrence of superfoetation in hares had been analysed critically by $\mathrm{Kn}$ a u s (1966 and 1967) who regards the period of prenatal regression of the corpus luteum, taking place during the final 24 hours of pregnancy, as the sole opportunity for heat and ovulation in doe-hares at time of gestation. However, the facts reported by the earlier mentioned authors remain unquestionable. The reproductive tract of female beaver no. 24 which died at parturition precludes the possibility of fertilization during the prenatal period, in spite of the development of Graafian follicles in the ovary.

The two cases of superfoetation in European beaver described above suggest this anomaly in reproduction of beavers to be a hindrance in parturitions leading to death of at least of a partion of kits. Obviously it does not increase fertility of this species. Superfoetation in an abnormal and undesirable phenomenon in beaver breeding, yet hard to eliminate under the present system of keeping breeding animals in reproductive pairs. Possibly, the occurrence of superfoetation in animals bred a farm 
is caused by Whit ten's effect (1956) and an incomplete pregnancy block (B r u ce, 1959).

\section{REFERENCES}

1. B a giński S., 1969: Technika mikroskopowa. Państw. Wyd. Nauk.: 1-708. Warszawa.

2. Bilewicz S. \& Minkiewiczowa Z., 1954: Cztery przypadki nieprawidłowego rozrodu u białych myszy. Folia biol., 2, 2: 113-121.

3. Bloch S., Hediger H., Lloyd H. G., Müller C. \& Straus S F., 1967: Beobachtungen zur Superfetation beim Feldhasen (Lepus europaeus). Z. Jagdwiss., 13, 2: 49-52.

4. Bruce H. M., 1959: An exteroceptive block to pregnancy in the mouse. Nature (London), 184: 105-106.

5. Burrows H., 1941: The bearing of a second litter by certain rodents without mating after the first parturitions. Vet. J., 97: 225.

6. Doboszyńska T., 1974: Histomorfologia układu rozrodczego samicy bobra europejskiego (Castor fiber L.) Diss., Akademia Rolniczo-Techniczna w Olsztynie, $1-91$.

7. Gienc J. \& Doboszyńska T., 1972: Macromorphological description of the genital organs of the female beaver. Acta theriol., 17, 30: 399-406.

8. Hediger H., 1948: Die Zucht des Feldhasen (Lepus europaeus Palla s) in Gefangenschaft. Phys. comp. et Oecol., 1: 46.

9. Jacobs W., 1966: Nachgewiesene Superfötation beim Feldhasen (Lepus europaeus). Z. Jagdwiss., 12, 3: 138.

10. Kna u s H., 1966: Zur Frage der Superfetation beim Feldhasen. Z. Jadgwiss., 12, $1: 1-5$.

11. Knaus H., 1967: Zur Frage der Superfetation beim Feldhasen. Z. Jagdwiss., 13, $2: 52-53$.

12. Krupiński L., 1955: Nowa metoda barwienia rozmazów pochwowych. Folia biol., 3, 3: 275-294.

13. Nalbandov A. V., 1966: Fizjologia rozrodu. Państw. Wyd. Nauk.: 1-302. Warszawa.

14. R o $11 \mathrm{~h}$ ä u s e r H., 1949: Superfoetation in a mouse. Anat. Rec., 105: 657-663.

15. Slon aker J. R., 1934: Superfoetation in the albino rat. Amer. J. Physiol., 108: $322-323$.

16. Smith Buchanan A. D., 1927a: A case of superfoetation in the pig. J. Anat., 61: 329-332.

17. Smith Buchanan A. D., 1927b: Further cases of superfoetation in pigs and sheep. J. Anat., 62: 100-104.

18. Whitten W. K., 1956: Modyfication of the oestrus cycle of the mouse by external stimuli associated with the male. J. Endocr. 13: 339-404.

19. Żurowski W., Kisza J., Kruk A. \& Roskosz A., 1974: Lactation and chemical composition of milk of the European beaver (Castor fiber L.). J. Mammal., 55: 847-850.

Accepted, September 1, 1974.

Polish Academy of Sciences, Institute of Genetics and Animal Breeding

Popielno, 12-222 Wejsuny, Poland.

Agricultural and Technical Academy, Institute of Fundamental Vet. Sciences 10-957 Olsztyn - Kortowo, Poland. 
Wirgiliusz ŻUROWSKI i Teresa DOBOSZYŃSKA

\section{SUPERFETACJA U BOBRA EUROPEJSKIEGO}

\section{Streszczenie}

Opisano 6 przypadków występowania objawów rui u samic (Tabela 1) bobra europejskiego (Castor fiber Linnaeus, 1758) skutecznie wcześniej pokrytych. Badania histologiczne jajników i dróg rodnych padłych samic oraz rozmazy pochwowe wskazywały na wysoką aktywność jajników samic ciężarnych. W dwóch nienormalnych miotach dwóch różnych samic obserwowano rodzące się młode różniące się między sobą wielkością i stopniem owłosienia. W jajnikach jednej z tych samic, padłej przy porodzie, stwierdzono obecność ciałek żółtych w różnym stopniu rozwoju. Fakty te wskazują na możliwość występowania superfetacji u bobra (Tablica I-II). 


\section{EXPLANATION TO PLATES}

Plate I

Fig. 1. Uterus with three resorbed embryos of different sizes, 1,2 and 3. No. 49 female.

Fig. 2 Cross-section of ovary showing different stages of corpus luteum formation, just after ovulation, and a corpus luteum of pregnancy.

1 - corpus luteum of pregnancy, 2-corpora lutea in the process of formation. No. 36 female. Mallory's staining method.

Fig. 3. Developmental stage of the uterus - closed lumen, high cylindrical epithelium, high tubules of the uterine glands. No. 49 female.

Haematoxylin-eosin staining.

Fig. 4. Proliferation of vaginal epithelium. Formation of a layer of keratotic cells. No. 49 females. Haematoxy'in-eosin staining.

Fig. 5. Cross-section of ovary showing corpora lutea of pregnancy in full development beside atressing corpora lutea.

1 - corpus luteum of pregnancy in full development, 2-corpus luteum of pregnancy in the process of atrophy, 3 - mature Graafian follicle. No. 24 female. Mallory's staining method.

Plate II

Fig. 6. Low epithelium protection the mucous membrane of the uterus; uterine glands - inactive. No. 24 female. Haematoxylin-eosin staining.

Fig. 7. Mucous membrane of the vagina. Low, non-keratotic epithelium with nucleate cells. No. 24 female. Haematoxylin-eosin staining. 


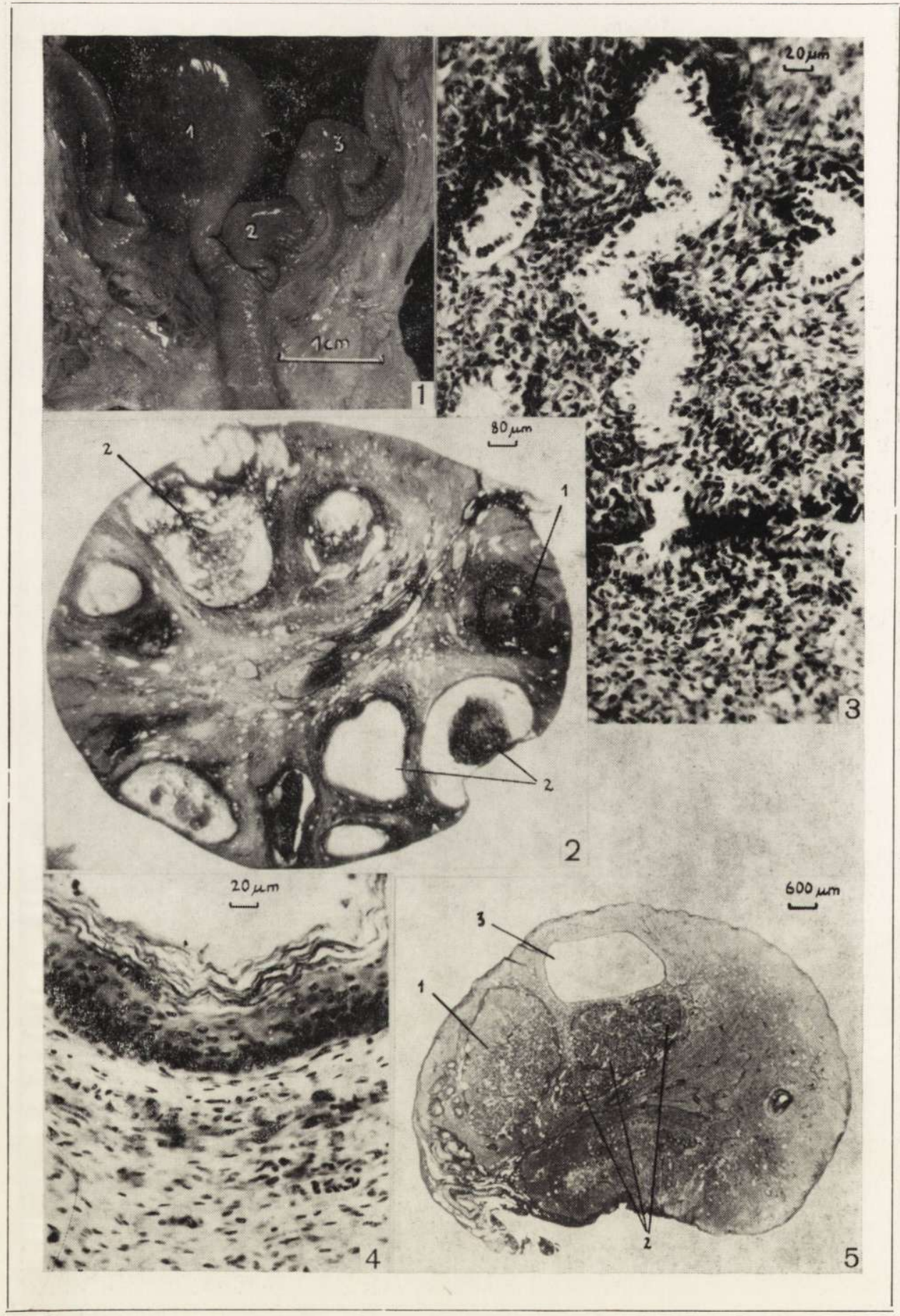

W. Żurowski \& T. Doboszyńska 
ACTA THERIOLOGICA, Vol. XX, 7.

Plate II

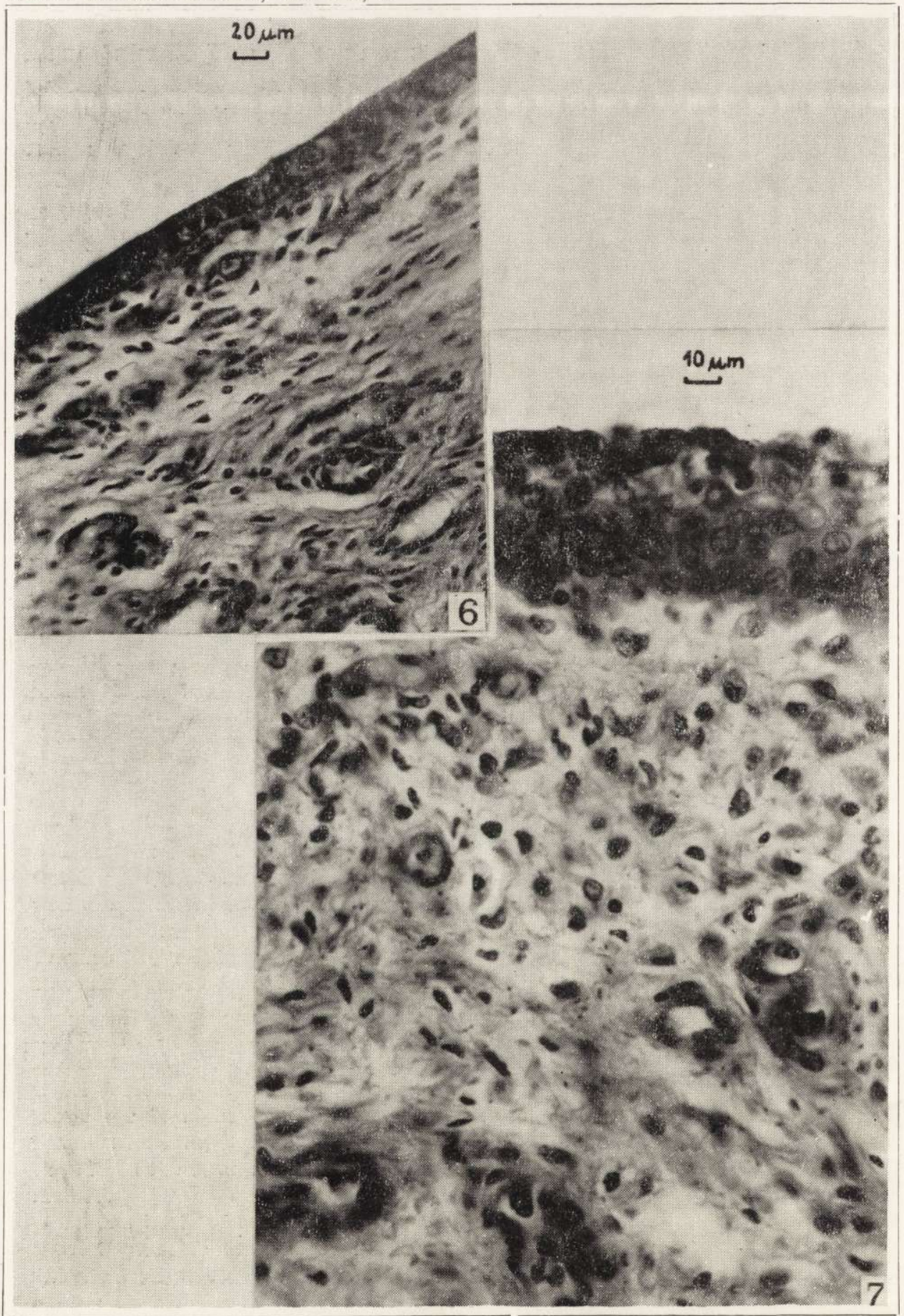

W. Żurowski \& T. Doboszyńska

C. Nagięć phot 